\title{
Recent Advances in Biopolymeric Composite Materials for Tissue Engineering and Regenerative Medicines: A Review
}

\author{
Muhammad Umar Aslam Khan 1,2,3,*(D), Saiful Izwan Abd Razak ${ }^{2,4}$, Wafa Shamsan Al Arjan ${ }^{5}$, Samina Nazir ${ }^{5}($, \\ T. Joseph Sahaya Anand ${ }^{6}\left(\mathbb{D}\right.$, Hassan Mehboob ${ }^{7}{ }^{\circledR}$ and Rashid Amin ${ }^{8, *}$
}

1 Department of Polymer Engineering and Technology, University of the Punjab, Lahore 54590, Punjab, Pakistan

2 School of Biomedical Engineering and Health Sciences, Faculty of Engineering, Universiti Teknologi Malaysia, Skudai 81300, Johor, Malaysia; saifulizwan@utm.my

3 School of Biomedical Engineering, Med-X Research Institute, Shanghai Jiao Tong University (SJTU), 1954 Huashan Road, Shanghai 200030, China

4 Centre for Advanced Composite Materials, Universiti Teknologi Malaysia, Skudai 81300, Johor, Malaysia

5 Department of Chemistry, College of Science, King Faisal University, P.O. Box 400, Al-Ahsa 31982, Saudi Arabia; walarjan@kfu.edu.sa (W.S.A.A.); seegasami.samina@gmail.com (S.N.)

6 Sustainable and Responsive Manufacturing Group, Faculty of Mechanical and Manufacturing Engineering Technology, Universiti Teknikal Malaysia Melaka, Hang Tuah Jaya, Melaka 76100, Malacca, Malaysia; anand@utem.edu.my

7 Department of Engineering Management, College of Engineering, Prince Sultan University, Rafha Street, P.O. Box 66833, Riyadh 11586, Saudi Arabia; hmehboob@psu.edu.sa

8 Department of Biology, College of Sciences, University of Hafr Al Batin, Hafar Al-Batin 39524, Saudi Arabia

* Correspondence: umar007khan@gmail.com (M.U.A.K.); rashida@uhb.edu.sa (R.A.)

\section{check for}

updates

Citation: Aslam Khan, M.U.; Abd Razak, S.I.; Al Arjan, W.S.; Nazir, S.; Sahaya Anand, T.J.; Mehboob, H.;

Amin, R. Recent Advances in Biopolymeric Composite Materials for Tissue Engineering and Regenerative Medicines: A Review. Molecules 2021, 26, 619. https:// doi.org/10.3390/molecules26030619

Academic Editor: Samy Madbouly Received: 13 November 2020 Accepted: 31 December 2020 Published: 25 January 2021

Publisher's Note: MDPI stays neutral with regard to jurisdictional clai$\mathrm{ms}$ in published maps and institutional affiliations.

Copyright: (C) 2021 by the authors. Licensee MDPI, Basel, Switzerland. This article is an open access article distributed under the terms and conditions of the Creative Commons Attribution (CC BY) license (https:// creativecommons.org/licenses/by/ $4.0 /)$.

\begin{abstract}
The polymeric composite material with desirable features can be gained by selecting suitable biopolymers with selected additives to get polymer-filler interaction. Several parameters can be modified according to the design requirements, such as chemical structure, degradation kinetics, and biopolymer composites' mechanical properties. The interfacial interactions between the biopolymer and the nanofiller have substantial control over biopolymer composites' mechanical characteristics. This review focuses on different applications of biopolymeric composites in controlled drug release, tissue engineering, and wound healing with considerable properties. The biopolymeric composite materials are required with advanced and multifunctional properties in the biomedical field and regenerative medicines with a complete analysis of routine biomaterials with enhanced biomedical engineering characteristics. Several studies in the literature on tissue engineering, drug delivery, and wound dressing have been mentioned. These results need to be reviewed for possible development and analysis, which makes an essential study.
\end{abstract}

Keywords: biopolymers; composite materials; tissue engineering; regenerative materials; wound dressing

\section{Introduction}

Recently, biopolymers have attained enormous attention with perspective multifunctional and high-performance biocomposites having a low environmental impact with unique properties like, abundantly available, renewable, eco-friendly, and lightweight. Biopolymeric composites should substitute synthetic materials in optics, biochemistry, and biomedical engineering with versatile applications, and investment and research on these materials increase significantly. Biopolymers and biodegradable synthetic polymers have attracted researchers' enormous attention in recent years [1,2]. Such materials have shown a significant role in synthesizing various biomaterials to serve diverse applications in medical science. The 'green', sustainable, biodegradable, and 'eco-friendly' polymeric composite materials with renewable and recyclable potential are desired in biomedical 
applications. Environmental protection is a motivating impulse behind such production of polymeric composites [3]. As recycling approaches are very expensive, the environmental factors related to continuous plastic-based pollution are causing serious global concerns.

Furthermore, the oil resources are limited and costly, thus adding to the recycling problems. Biopolymeric composite materials will potentially resolve the environmental sustainability-pollution conflicts and will decrease fossil fuel dependency [4,5]. Thus, the emphasis was laid on biocompatible and biodegradable polymeric composite materials.

Production of durable, stronger, and lightweight multifunctional biopolymeric materials is desired for biomedical applications. However, developing or choosing approaches to meet the architectural design challenges requires a compromise between visions and objectives, usually conflicting in novel biomaterials [6,7]. It can be further discussing as follows.

(i) Biopolymers: Types of polymers obtained from biological resources, such as living organisms and plants. These are also known as biological macromolecules, biological polymers, or biopolymers.

(ii) Derived biopolymers are polymers that are chemically modified, and their monomers are derived from biopolymers as a starting material like polysaccharides, polypeptides, and other biopolymers.

\section{Biopolymers}

The polymers obtained from living resources or biological origin, including plants, animals, or microorganisms, and their system biology processes are called natural polymers. Carbohydrates, i.e., arabinoxylan, chitosan and starch, proteins, e.g., gelatin and keratin, and polyhydroxyalkanoates (PHAs) such as poly-(3-hydroxybutyrate) $[\mathrm{P}(3 \mathrm{HB})]$, are all known as biopolymers [8]. Biopolymeric composite materials' synthesis employs one or more biopolymers to enhance structural and functional properties in the resulting composites [9]. A biopolymer's composition influences its functional properties, whereas functional potential depends largely on the crystalline or amorphous materials' behavior. For example, cellulose is a structural polymer where its features are partly due to its crystalline nature.

Nonetheless, physical, chemical, and biological action can turn them into useful multifunctional materials for several purposeful applications [10]. The chemically altered biopolymers, e.g., thiolated arabinoxylan and cellulose acetate, were used in several potential medical and a wide range of applications as shown in the Figure 1. Modified polysaccharides have been extensively used in paint, cement, adhesives, cosmetics, antibacterial coating, medicines, and many other products [11,12].

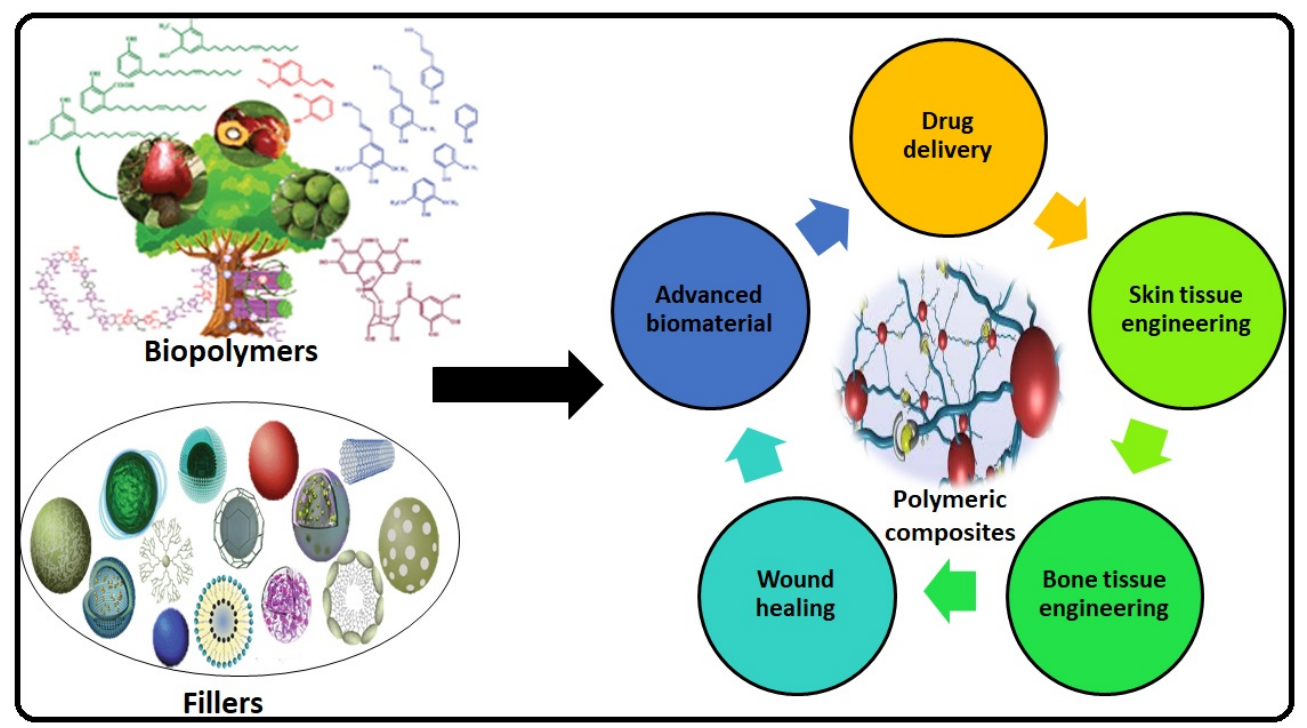

Figure 1. Graphical abstract that describes the different potential application of biopolymers with different fillers. 
Chitosan is a well-known compound from the carbohydrate polysaccharide family. It has gained popularity due to bio-sustainability, biodegradability, and compatibility in various fields. It is easily produced from marine sources (lobsters, crabs, shrimp, etc.) and can be used in different biopolymeric composite materials [13]. Among the carbohydrates, arabinoxylan is also a well-known bio-polymers with several potential medicinal applications $[14,15]$. There are many problems to be considered, such as technical and manufacturing issues before the widespread use of bio-sustainable polymers is possible. An essential obstacle to the broader use of biopolymers in various sectors is their functional characteristics that appear to be unfavorable compared with established petroleum-based polymers. For example, their performance is lower than that of plastic materials since the structural nature of a part of biopolymers with single bonds leads to lower mechanical characteristics [16,17]. These deficiencies can be resolved in various ways, such as grafting, mixing, blending, and reinforcing with other appropriate polymers and ceramics.

\section{Biopolymer Types}

Polymeric composites come from a wide range of sources, from common synthetic materials (petroleum-based) including polystyrene to natural biopolymers like cellulose, proteins, and microbial polyesters, which are important for biological structure and function $[18,19]$. A broader spectrum of these polymeric materials has been categorized as natural or synthetic according to their source's nature, as presented in Figure 2. Biopolymers or bio-based polymer composites can be classified into three main categories, depending on their source.

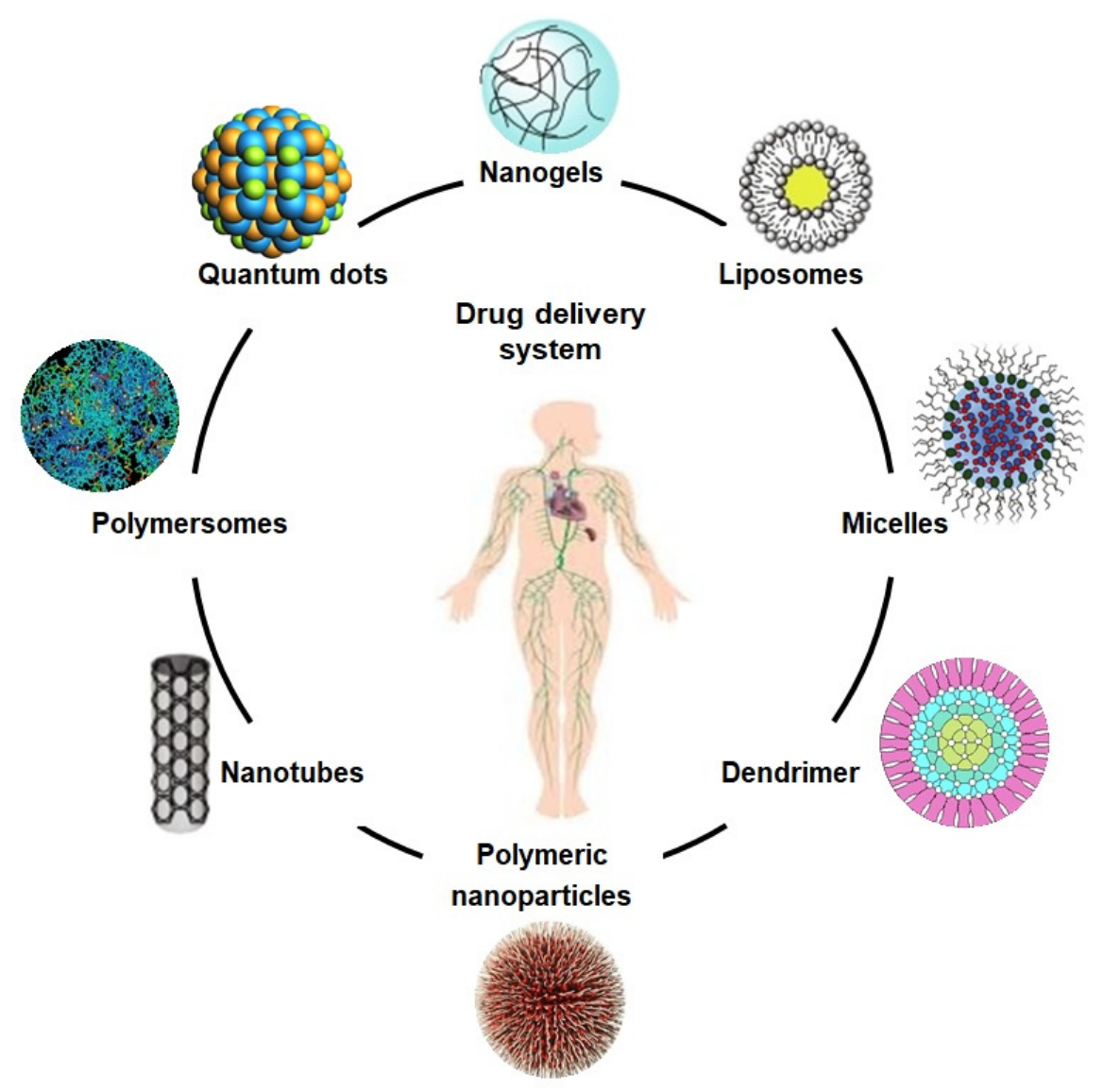

Figure 2. The schematic diagram illustrates different drug carriers for the drug delivery system.

Category 1: Polymers extracted or separated from biomass, such as starch, cellulose, arabinoxylan, and keratin. 
Category 2: Polymers obtained from standard chemical processing using renewable biopolymer originated monomers such as polylactic acid (PLA), cellulose acetate (CA), etc., are produced through the fermentation of carbohydrate feedstock.

Category 3: Polymers acquired from microorganisms processing, e.g., mainly PHAs, but bacterial cellulose is under development.

\section{Bio-Composites}

A composite is a generally recognized material composed of one to several different materials or polymers with a marked difference in chemical or physical properties. Composites are used to produce customized properties through enhancing or imparting certain features that cannot be demonstrated by particular homogeneous substances. When polymeric composites contain specific biological phases, they are defined as bio-composites [20-22]. Biocomposite materials are synthesized from natural or bio-derived polymers, e.g., chitosan, arabinoxylan, PHAs, or PLA. Efficient and sustainable bio-composites produced from biopolymeric/natural materials and degradable inorganic fillers are called green composite materials. They are the subject of attention because of environmental issues and regulations $[23,24]$. Bio-based composite materials have currently been produced to target issues in various sectors, like bio-based packaging, biomedical, pharmacy, textile, paper, and others, etc. $[25,26]$. It started resolving the increasing environmental challenges globally raised by unsustainable non-renewable petroleum resources. Due to growing environmental awareness and regulatory agencies' requirements, the production and utilization of conventional synthetically manufactured polymers or composite structures are more critically considered [27]. Biopolymers are quite stable materials obtained from various natural resources. They are biodegradable and can be easily recycled, commercially and ecologically viable, and therefore labelled as bio-sustainable products. Environmental factors and microbial decomposition help them degrade to a favorable environment after disposal [25]. The composites of biopolymers, which are biodegradable as well as biocompatible, are termed as "green biocomposites". Different green biocomposites are reported with numerous inorganic fillers, which includes titania, silica and alumina, etc. [28,29]. Bio-plastic developments delivered a range of feasible and environment friendly products to perform on market already lead by the petroleum based synthetic materials [25].

\section{Biomedical Applications of Biopolymeric Composite Material}

The biopolymers like arabinoxylan, chitosan, guar gum, and xyloglucan have potential benefits over synthetic polymers. These provide a fundamental variety of alternatives in biomedical science for efficient polymeric biomaterials and composite materials. Polysaccharides are potential candidates to give multi-functional, biocompatible, mechanically stable, sustainable, and biodegradable materials. Henceforth, they are emerging as ideal candidates for synthesizing novel composite materials, offering therapeutic efficacy and controlled drug release pertinent for several biomedical applications, and wound remedial and tissue engineering [30]. The polysaccharide-based biopolymeric composites can be employed to fabricate numerous biomaterials like films, fibres, hydrogel, and scaffolds with multifunctional approaches in biomedical engineering.

\subsection{Drug Delivery}

Composites based on polysaccharides, including arabinoxylan, chitosan, and xyloglucan have exhibited an innovative potential as carriers to deliver therapeutic agents, including genes, biomolecules, and biological drugs, as shown in Figure 2. These are used as drug carriers for cancer treatment, cartilage repair, and vascular grafts with excellent biocompatibility, low cytotoxicity, non-antigenicity, process-ability, reversible charging, and releasing mechanisms. Emulsification, gel formation, foaming, and moisture absorption capacities are other assets that enhance their drug delivery application [31-33]. Due to their unique mechanical and crosslinking characteristics, desirable biodegradation in different media, and on the targeted sites, these polymeric materials have also been recognized 
as efficient controlled drug delivery systems [34]. Such biomaterials can be synthesized directly or are incorporated with multifunctional characteristics to engineer specific and targeted sites on resulting nanocarriers. Some reported biomaterials varieties are based on chitosan, guar gum, and arabinoxylan, etc., and have been used efficiently as hydrogels, films, tubes, microspheres, and microneedles [35].

Controlled drug delivery aims to administer therapeutic agents at a steady speed and maintain the effective therapeutic window at the targeted site, usually in blood. It offers economic and desirable therapeutic results that decrease or remove dose-related adverse side effects and toxicity complications and increase patient recovery and comfort. It is believed that the most desirable drug features from biomaterial systems are controlled degradation and sustainable release after accumulation at the targeted site [36]. This controlled release of embedded drugs or any therapeutic agents can be regulated mostly by a trigger such as a temperature, $\mathrm{pH}$, and concentration of ions [30]. In general, the difference between the extracellular matrix's $\mathrm{pH}$ for healthy tissues is 7.4, and in cancer tissues, it is 6.5. Consequently, $\mathrm{pH}$-sensitive polymeric medicines have been efficiently developed for targeted cancer drug delivery $[37,38]$.

The targeted drug delivery system usually needs to activate the cellular sites for a controlled release of therapeutic payloads. Accordingly, a customized drug delivery approach needs to optimize precursors' synthesis or functionalization, composite manufacturing conditions, and drug encapsulation strategy to fit well with the desired release kinetics $[39,40]$. Henceforth, all parameters such as size, shape, surface morphology, bioavailability, and biodegradability should be suitable and site-specific to deliver drugs or other nutrients at the targeted site with a controlled rate and dosage [41-44]. The biomimetic polymeric nanoparticles were synthesized with different sizes and achieved an effective loading of therapeutic agents. Such precise nano drug-carriers helped for molecular imaging of inflamed sites and resolved potential inflammations and immune responses [45,46].

\subsection{Tissue Engineering}

Tissue engineering involves the synthesis of biomaterial scaffolds to treat or regenerate defective tissue, as illustrated in Figure 3. It requires polymeric composite materials with the required composition, desired engineering properties, and adequate physicochemical behavior to support biological tissue growth [47]. After being listed as a subfield of biomaterials, it has grown in depth and significance like an advanced field of its own. Since tissue engineering addresses various applications, the effect is generally associated with applications that replace, repair, or reconstruct part or whole tissue (i.e., bone, cartilage, blood vessels, bladder, skin, muscle, etc.) [48,49]. The tissues concerned often require that certain architectural, morphological, and mechanical properties work properly. Tissue engineering term has also been used to incorporate complex biochemical pathways via cells within the artificially generated protection and support system (e.g., skin, hip replacement, etc.). A schematic diagram has been presented of the role of different biomaterials in tissue engineering in Figure 3.

Tissue engineering was, therefore classified into two types:

Bone tissue engineering.

Skin tissue engineering. 


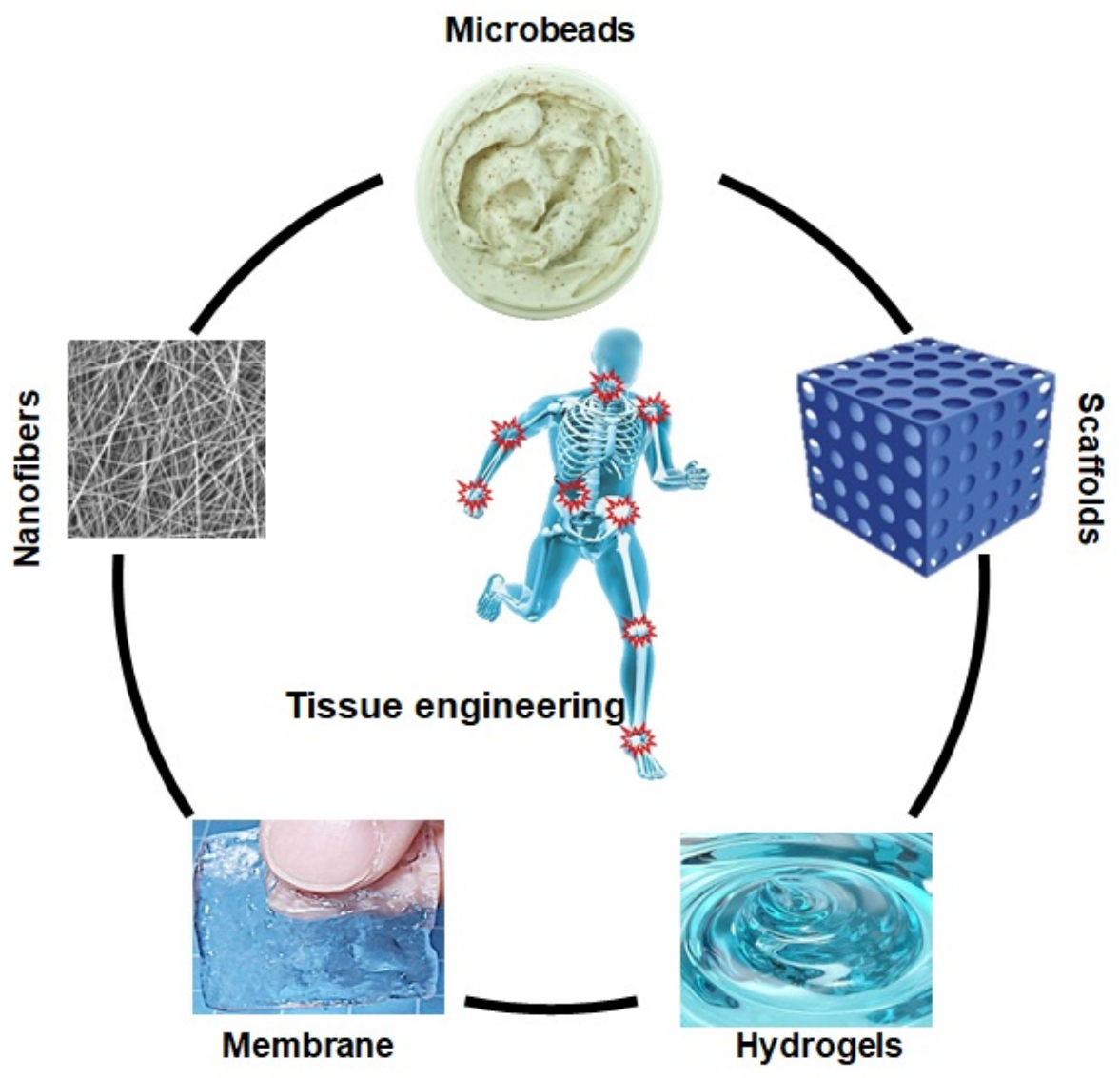

Figure 3. Biopolymer based different form of biomaterials in tissue engineering.

\subsubsection{Bone Tissue Engineering}

Bone tissue engineering (BTE) is a capable technique that aims at 3D bone scaffolding, containing viable cells and bioactive molecules [50]. BTE focuses on the skeletal structure's perception, bone dynamics for tissue regeneration as it improves clinical abilities to treat disturbing skeletal and segmental abnormalities [51]. In other cases, the modern science of bone biochemistry and its development is necessary if bone tissue is to be effectively regenerated or restored. A bone may serve a wide multifunctional range that leads to physiological and endocrine stimulation.

Bones constitute the basis of our physical locomotion.

Bones support our load-bearing skeleton and our internal organs with safety.

The bones retain the necessary biological elements for hematopoiesis.

The bones adsorb highly toxic metals due to a porous matrix.

Bones retain vital electrolytes homeostasis by storing calcium and phosphate ions.

The bone undergoes a continuous resorption and reconstruction process that undergoes the exchange of chemicals and structural remodelling due to internal intermediaries and external mechanical standards. Bone was historically and most accurately named the ultimate intelligent material because of its scarce regenerative adaptability. Functional bone tissue engineering includes the fusion of the newly healed bone with the adjacent host bone and, most significantly, the native bone functions [52-54]. The bone is an extremely complex tissue due to functional and architectural diversity. The bone extracellular matrix (ECM) particularly consists of both an organic non-mineralized matrix and an inorganic mineralized component. The nanocomposite structure is important for the compressive strength needed and thigh bone fracture resistance and load-bearing applications [55,56]. In either case, cellular mesenchymal condensation occurs firstly that acts mostly as a platform for osteogenesis, and mesenchymal progenitor cells, extracellular matrix development is necessary. These cells differentiate in osteoblasts and ultimately build portions of the 
mandible, clavicle, and several other cranial bones. Furthermore, endochondral bone formation forms a substantial portion of bones. This technique includes the first differentiation of mesenchymal progenitors into the chondrocytes responsible for the deposition of a cartilage template that is later mineralized and replaced by bone [57-59].

Various engineering methodologies could include adequate extracellular matrix molecules or adherent ligands that stimulate stem cells and mediate earlier to regenerate bone tissues. Bone tissue engineering should be aimed at fabricating scaffolds to promote angiogenesis that incorporates growth factors and has the porous structure needed for vascular growth $[60,61]$. Tissue engineering of these scaffolds with micro and nano-meter surface morphology is essential for cellular adhesion, proliferation, and differentiation [62,63]. More broadly, the development of polymeric scaffolds can enhance osteogenesis that encourages the remodelling of tissues. Effective bone regeneration needs to support the function of bone tissue.

Subsequently, bone tissue therapies in hospitals need a more definitive strategy, such as using in-vitro scaffold regeneration machines to restore bone functions in vivo. 3D printing or additive manufacturing (AM) has been frequently used in different industries, including construction, design and development, biomechanical, and tissue engineering $[64,65]$. The key advantage of $3 \mathrm{D}$ printing is the opportunity to produce complicated shapes, as it can produce parts of different sizes from micro to macro and allow fast prototyping. Producing products via 3D printing has reduced the additional costs, and personalized products can be printed in small quantities [66]. The most common materials involved in 3D printing are polymers, metals, ceramics, and concrete [65].

Nonetheless, poly(lactic) acid (PLA) is among the synthetic polymers used primarily for 3D scaffold printing [67]. It is necessary to choose the right biopolymer to have the desired tissue engineering features, and the scaffold may work properly after implantation [61]. Some ideal composite biomaterials based on biopolymers have been reported as a better option for the potential tissue engineering system (Table 1).

Table 1. Polymeric composite materials in tissue engineering.

\begin{tabular}{ccccc}
\hline Sr. No & Polymers & Salient Features & References \\
\hline 1. & Chitosan & Biodegradable, biocompatible, antibacterial, cytocompatible, bioactive & {$[68-71]$} \\
2. & Gelatin & Bioactive, biocompatible, hemocompatible, cell adherence, anti-thrombogenic & {$[72-75]$} & {$[14,76,77]$} \\
3. & Arabinoxylan & Biocompatible, antibacterial, cell adherence, bioactive, cell proliferation & {$[70,78-80]$} \\
4. & Collagen & Biodegradable, fibrous, biodegradable, cell proliferation & {$[81,82]$} \\
5. & Xyloglucan & Cell proliferation, biodegradable, cell differentiation, biocompatible & [83-86] \\
6. & Fibrinogen & Biocompatible, hemocompatibility, cell proliferation, biodegradable, cytocompatible & [87-90] \\
7. & Hyaluronic acid & Bioactive, cell adherence, cell proliferation, cell differentiation, biocompatible & [91-93] \\
\hline 8. & Beta-glucan & Biocompatible, bioactive, biodegradable, antibacterial, mechanical &
\end{tabular}

\subsubsection{Skin Tissue Engineering}

The skin is considered one of the most sensitive organs due to its multi-functional roles, such as acting as a protecting enclosure for internal organs' safety, regulating the body's temperature, and acting as a sense organ [93,94]. Normal skin consists of three components known as epidermis, dermis, and hypodermis.

The outmost waterproof layer is the epidermis, which acts as a defensive barricade against pathogens and foreign materials, and plays a critical role in body temperature and humidity regulation $[95,96]$. Keratinocytes make up more than $90 \%$ of most cells of the epidermis. The majority of the epidermal cell population is dominated by Langerhans, Melanocytes, and Merkel cells [97]. Dermis makes up about $90 \%$ of the skin's weight and forms the skin's base $[95,98]$. It is a soft tissue composed of extracellular matrix (ECM), many types of cells, glands, and hair follicles. The dermis layer is well-vascularized by blood vessels and contains nerve endings. Fibroblasts are the largest dermal cells, which contain collagen and elastin, and provide mechanical strength and elasticity to the skin $[99,100]$. The hypodermis is a deeper level of elastic fibrous tissue with mucous 
properties, skin cells that store fat, blood vessels, and nerves [101,102]. Traumas such as physical piercing, poisoning, fire, disease, or surgery damage this main organ and lead to the vital organs at risk of infection, injury, or dehydration. Skin replacement tissue engineering provides a potential basis for better care in the fight against chronic and acute skin wounds $[103,104]$. However, as the mechanical and physiological parameters of active skin concerns, the skin tissue engineering necessitates having a cell base and simulated extracellular matrix (ECM) to communicate with the surrounding tissue [105]. There are currently no major skin prototypes that accurately reproduce the structure, composition, organic consistency, or visual atmosphere of natural skin. Skin alternatives may have important features as easy to use and specific to the type or the position of the wound. These biomaterials have adequate aquatic fluidity and special adherents towards host sites [106,107]. They have sufficient biochemical and mechanical properties, have controlled deprivation, are disinfected, non-toxic and non-antigenic, and have negligible inflammatory effects. They can also join the congregation with minimal harm and angiogenesis pain while still at operating costs. The ultimate goal of tissue engineering is to attain the maximum of these requirements to prepare smart skin replacements [97,108-110]. Earlier skin replacements faced failure, contamination, and defects, which led to the restricted use of autographs and allografts. Recently, synthesized skin substitutes have developed with the multifunctional properties. Henceforth, the extension of an imitated skin provides relief for patients with burns and other skin-related disorders [111-113]. These studies provide a summary of the improvements and potential alternative materials for skin care and treatment to regenerate targeted tissues.

Autologous keratinocytes are formed and grown in interconnected layers of the epithelium, and these are substituted for those with large skin deficiencies. Approximately, after more than 140 replications, we can isolate clonogenic keratinocytes or holoclones from the skin and gradually increase culture. In many studies related to tissue engineering, polymeric materials have multifunctional properties to support stem-cell growth and differentiation. These studies have been proved multifunctional properties of polymeric material to grow stem cells based on their abilities to regenerate various skin lines $[114,115]$. The stem cells embedded in epidermal layers promote the repair and regeneration of the epidermis. The growth of epidermal stem cells in allogeneic dermis or fibrin has proved suitable for quick growth and regeneration processes [116]. Growing epidermal stem cells as autologous sheets to cover the major epithelial area, in cases such as burns, take only more than a few weeks $[103,117]$. In this way, mounting stem cells on a polymeric material from a minor skin biopsy reduces the time required to label outsized epithelial layers. Besides, fibrin or allogeneic dermis epidermal stem cells maintain their wound healing ability $[118,119]$. Somehow, such epidermal stem cell implants lack adequate skin regeneration. Efforts to integrate the sophisticated epidermal parts such as hair follicles, sweat glands, and sebaceous glands could not meet success, which indicates that multifaceted connexions of epithelial and mesenchymal layers are important for the generation of additions $[120,121]$. Furthermore, the polymeric composite materials do not reinstate the novel skin's electronic properties or visual structure. Changes in stem cell biology and skin morphogenesis are necessary for extending skin developments, delivering the usual usefulness and aesthetics of healthy skin [122].

\subsection{Wounds Healing}

Wounds are an irregular skin puncture, breakage, or deformity of the skin due to thermal/physical damage or chronic disease [123]. Depending on the healing technique, the wounds may be listed as chronic or acute wounds. Chronic wounds are mainly tissue lesions that appear to settle completely, typically within 8 to 12 weeks. Acute injuries continue to reappear and still have a recovery time of more than 12 weeks [124-126]. Different neural aspects can lead to impaired wound healing of a wound or an inability to heal properly. Examples of chronic wounds include bedsores (ischemic or venous) and leg ulcers $[127,128]$. Skin layers and contaminated sites are used as a basis for wound gradation, 
and surface wounds involve only the epidermal skin surface. The word "partial-thickness wound" refers to injuries affecting the epidermis, deep epidermis layer, muscles, soft tissue, and follicles. Besides the epidermis and the dermal surface, wounds of maximum thickness are associated with subcutaneous fat or deep tissue [129-131].

The physiological regeneration of wounds includes coordinated cooperation between different biological systems. It comprises a cascade of regulated activities to heal a wound completely. Hysteresis and blood clotting begins as a lesion, occurs in any part of the body, and the main objective of such processes is to prevent instant exsanguinations. This lesion is also a secondary long-term target and a matrix for adhesion to invading cells $[132,133]$. Homeostasis and the quantity of fibrin produced at the injury site are dependent on a properly regulated balance of the endothelial cells, thrombocytes, coagulation, and fibrinolysis. Vascularization is caused by the neurological reflex system in impaired vessels, thereby blocking blood flow for several minutes. Homeostatic behaviors and proliferation and differentiation cause the waterfall of coagulation [134,135]. Platelets bind to the extracellular matrix when blood spills, inducing the clotting factor's release: fibronectin, fibrin, vitronectin, and thrombospondin. Clotting retains homeostasis and a matrix for migrating cells in corresponding to homeostatic and inflammatory procedures [136-138].

Many biopolymers, including fibrous proteins and various polysaccharides, are commonly engaged in wound care and treatment. These biocompatible, biodegradable polymeric matrixes maintain an atmosphere analogous to the extracellular environment and speed up the usually slow wound healing process $[15,139,140]$. The biopolymeric matrix offers an excellent micro-environment for cell adhesion, proliferation, cell migration, and differentiation. Three-dimensional crosslinked polymeric networks can maintain enough moisture and oxygen-based on wound treatment materials made from biopolymers at the wound site. The wound healing dressings promote regeneration, prevention, and protection of the wound, especially from severe disease-causing pathogens. It is important for repairing and regenerating the dermal and epidermal tissues [141]. These wound healing materials are recognized as hydrogels that can be packed with spatially and temporally regulated cells, medicines, and peptides for localized therapeutic delivery $[142,143]$. Biopolymeric based potential biomaterial has been summarized in Table 2 .

Table 2. Biopolymeric materials as a potential biomaterial in wound healing.

\begin{tabular}{|c|c|c|c|}
\hline Sr. No & Polymers & Salient Features & References \\
\hline 1. & $\begin{array}{l}\text { Arabinoxylan/guar } \\
\text { gum/gelatin/collagen }\end{array}$ & $\begin{array}{l}\text { antibacterial, biocompatible, biodegradable, bioactive, } \\
\text { sustained drug release, cell proliferation }\end{array}$ & {$[15,144-147]$} \\
\hline 2. & Beta-glucan/chitosan & $\begin{array}{l}\text { biocompatible, antibacterial, cell proliferation, bioactive, } \\
\text { bioactive molecule release, adherence }\end{array}$ & [148-154] \\
\hline 3. & $\begin{array}{l}\text { Alginate/Fibrinogen/ } \\
\text { Hyaluronic acid/xyloglucan }\end{array}$ & $\begin{array}{l}\text { Fibrous protein, biocompatible, biodegradable, fibrous, } \\
\text { antibacterial, cell adherence, cell proliferation }\end{array}$ & [155-163] \\
\hline 4. & Bacterial cellulose/pectin/carrageenan & $\begin{array}{l}\text { antibacterial, cell adherence, cell differentiation, } \\
\text { biocompatible, bioactive, cytocompatible }\end{array}$ & [164-169] \\
\hline 5. & Fucoidan/Silk sericin/keratin & $\begin{array}{l}\text { anti-coagulant, anti-inflammatory, anti-viral, anti-tumor, } \\
\text { anti-thrombic }\end{array}$ & [170-176] \\
\hline 6. & $\begin{array}{l}\text { Bovine serum/agar/ } \\
\text { Acetobacter xylinum }\end{array}$ & $\begin{array}{l}\text { cell proliferation, cell adherence, biocompatible, } \\
\text { bioactive, antibacterial, cytocompatible }\end{array}$ & {$[164,177-182]$} \\
\hline
\end{tabular}

Hydrogels were utilized in biomedical research and clinical applications, including tissue engineering, regenerative medicine, cancer treatment, infectious diseases, controlled drug delivery, and peptide delivery $[183,184]$. The loading and subsequent release of bioactive molecules into hydrogels can be managed by regulating the crosslinking rate, which results in many pharmacokinetics control options for developing optimum hydrogel-releasing therapeutics agents or bioactive molecules [185-188]. Hydrogels can progressively elucidate chemotherapeutic drugs in local settings, which can help to discharge therapeutic agents 
systemically. The high moisture content of hydrogels and the physicochemical and biological similarities with the native extracellular atmosphere make them principally biocompatible and practicable for substantial therapeutic applications $[189,190]$. Hydrogels conform to the shape of the application site, making the formulation of loaded hydrogels much more clinically feasible in biomedical applications. While poly (ethylene glycol) (PEG) use in hydrogels was considered to be extremely biocompatible, e.g., PEG hydrogels, PEG-based hydrogels improve fibroblast growth rates [191,192]. PEG's high systemic biocompatibility and use of ECM-derived biomaterials improve cellular growth distribution. As a result, PEG-based crosslinked hydrogels evolve as multifunctional materials for wound care technology with favorable loaded materials like cells, drugs, and peptides [193-195].

\section{Advanced Functional Biomaterials}

A better understanding of the sequential, structural, and functional characteristics of natural polymers plays a substantial role in designing and synthesizing multifunctional polymeric materials. These advanced artificial biomaterials have abilities of self-assembly and stimuli response under certain conditions to promote cell interaction and proliferation [196-198]. The complexity of post-transcriptional alterations restricted the synthesis of advanced and multifunctional protein biomaterials utilizing bacterial resources, and the paradox of target genes being inserted into the sequences. Other modifications were designed to control spatial and temporal releases correctly. Advances in gene therapy and DNA manipulation methods have enabled structural, and de novo design developments for protein-based biomaterials [199-201]. These allowed the development of polymer composites of nano-size with considerable physicochemical and biochemical properties. These characteristics can be linked to essential design modules from a modular field of composite polymeric materials such as collagen, elastin, silk, and resilin [202-204]. The structure of such synthesized biomaterials is associated with great versatility, such as cell-binding sites and enzymatic domains, due to the presence of multi-functional domains on protein structure.

Recent developments in genetic engineering have promised the design and synthesis of advanced biomaterials based on artificial proteins. These biomaterials have unique performance compared to their native counterparts, such as enhancing the self-assembly into the fibrous structures [205,206]. Different cloning pathways, such as yeast, bacteria, plant, and mammalian cells have already been studied to express native and synthetic protein-based biopolymers [141]. These biopolymers imitate proteins' primary modular structure having distinct physicochemical and biological characterizations [207-209]. Escherichia coli (E. coli) is widely used to manufacture protein biopolymers such as silk, elastin, resilience, and other biomimetic proteins [144].

\section{Conclusions and Future Directions}

This review article aims to address the possible biopolymers, biocomposite materials, and potential applications in drug release, tissue engineering, wound healing, and advanced functional biomaterial. Previously, petroleum-based synthetic polymers were considered the best biomaterials in tissue engineering and regenerative medicines. Still, due to depletion in resources, biodegradability, eco-friendly and environmental sustainability make scientists and research to replace them with other biopolymers. The biopolymers are the best substitutes for synthetic polymers obtained from petroleum with considerable renewable, biodegradable, environmental, and eco-friendly properties. The biopolymers don't support mechanical properties like high tensile strength, impact strength, flexural strength, thermal stability, etc. However, their ceramic composites display sufficient mechanical strength to support load-bearing applications. Still, further attention, developments, and improvements are necessary. The traditional blending techniques have been adopted to tailor the microstructural properties of biocomposite by adding reinforcements. Sometimes, their structural properties are also enhanced by blending them with synthetic polymers (PVA, PMMA, etc.). Different fillers have been recently introduced into the biopolymers to prepare highly functional composites for the biomedical industry. 
Study in this field has grown dramatically in recent decades, which has been confirmed by the resulting rise in the number of newly published materials. In many industries, including packaging, vehicles, building, electronics, and most significantly, biopolymer composites find countless daily applications in medicine. The widely used biochemical recipes for biopolymer composites synthesis include injecting, extrusion, and in situ synthesis. The introduction of graphene and its derivatives as fillers into biopolymers strengthened their mechanical properties to obtain desired biomaterials, such as tensile, effect, flexural, and other structural properties. The metallic nanoparticles also have played a vital role as fillers to synthesize biocomposite to enable several opportunities to explore their innovative properties in medical applications. Mechanical behavior and poor dispersion are the major problems that limit the use of biopolymers to synthesize biocomposites. The fillers form agglomerates with a biopolymer matrix, resulting in poor interfacial bonding resulting in poor mechanical properties with poor structural uniformity. Such composites result in many other odd parameters, including high-temperature sensitivity, moisture sensitivity, low impact strength, and shelf life, etc. Future directions lead towards new biomaterial to address the stated factors and fit well with the economic viability, recycling processes and being eco-friendly.

Author Contributions: Conceptualization, M.U.A.K.; methodology, M.U.A.K. and S.I.A.R.; software, M.U.A.K. and W.S.A.A.; validation, S.I.A.R. and T.J.S.A.; formal analysis, M.U.A.K. and S.N.; investigation, S.I.A.R. and R.A.; funding acquisition, H.M.; resources, M.U.A.K., S.I.A.R. and T.J.S.A.; data curation, M.U.A.K., W.S.A.A. and S.I.A.R.; visualization, M.U.A.K.; supervision, S.I.A.R.; project administration, M.U.A.K., S.I.A.R. and T.J.S.A.; writing-original draft preparation, M.U.A.K.; writing-review and editing, M.U.A.K., S.N., S.I.A.R. and R.A. All authors have read and agreed to the published version of the manuscript.

Funding: The authors would like to appreciate Universiti Teknologi Malaysia for supporting this study under UTM-IIIG grant number 02M44. The authors like to acknowledge the funding contribution for article processing charges (APC) from Prince Sultan University, Riyadh, Saudi Arabia.

Institutional Review Board Statement: Not applicable.

Informed Consent Statement: Not applicable.

Data Availability Statement: Data presented in this study are openly available and cited in the references.

Conflicts of Interest: All authors have declared no conflict of interest.

\section{References}

1. Vroman, I.; Tighzert, L. Biodegradable polymers. Materials 2009, 2, 307-344. [CrossRef]

2. Ulery, B.D.; Nair, L.S.; Laurencin, C.T. Biomedical applications of biodegradable polymers. J. Polym. Sci. Part B Polym. Phys. 2011, 49, 832-864. [CrossRef] [PubMed]

3. Jawaid, M.; Swain, S.K. Bionanocomposites for Packaging Applications; Springer: Berlin, Germany, 2018.

4. Nižetić, S.; Djilali, N.; Papadopoulos, A.; Rodrigues, J.J. Smart technologies for promotion of energy efficiency, utilization of sustainable resources and waste management. J. Clean. Prod. 2019, 231, 565-591. [CrossRef]

5. Letcher, T.M.; Scott, J.L. Materials for a Sustainable Future; Royal Society of Chemistry: London, UK, 2012.

6. De Oliveira Barud, H.G.; da Silva, R.R.; da Silva Barud, H.; Tercjak, A.; Gutierrez, J.; Lustri, W.R.; de Oliveira, O.B., Jr.; Ribeiro, S.J. A multipurpose natural and renewable polymer in medical applications: Bacterial cellulose. Carbohydr. Polym. 2016, 153, 406-420. [CrossRef] [PubMed]

7. Berglund, L.A.; Burgert, I. Bioinspired wood nanotechnology for functional materials. Adv. Mater. 2018, 30, 1704285. [CrossRef]

8. Samadian, H.; Maleki, H.; Allahyari, Z.; Jaymand, M. Natural polymers-based light-induced hydrogels: Promising biomaterials for biomedical applications. Coord. Chem. Rev. 2020, 420, 213432. [CrossRef]

9. Gasperini, L.; Mano, J.F.; Reis, R.L. Natural polymers for the microencapsulation of cells. J. R. Soc. Interface 2014, $11,20140817$. [CrossRef]

10. Owens, G.J.; Singh, R.K.; Foroutan, F.; Alqaysi, M.; Han, C.-M.; Mahapatra, C.; Kim, H.-W.; Knowles, J.C. Sol-gel based materials for biomedical applications. Prog. Mater. Sci. 2016, 77, 1-79. [CrossRef]

11. Thomas, B.; Raj, M.C.; Joy, J.; Moores, A.; Drisko, G.L.; Sanchez, C.M. Nanocellulose, a versatile green platform: From biosources to materials and their applications. Chem. Rev. 2018, 118, 11575-11625. [CrossRef] 
12. Morin-Crini, N.; Lichtfouse, E.; Torri, G.; Crini, G. Applications of chitosan in food, pharmaceuticals, medicine, cosmetics, agriculture, textiles, pulp and paper, biotechnology, and environmental chemistry. Environ. Chem. Lett. 2019, 17, 1667-1692. [CrossRef]

13. Ramakrishnan, V.V.; Routray, W.; Dave, D. An Overview of Bioprocessing and Biorefinery Approach for Sustainable Fisheries. In Developing Technologies in Food Science; CRC Press: Boca Raton, FL, USA, 2017; Chapter 9; pp. 193-278.

14. Khan, M.U.A.; Haider, S.; Shah, S.A.; Abd Razak, S.I.; Hassan, S.A.; Kadir, M.R.A.; Haider, A. Arabinoxylan-co-AA/HAp/TiO2 nanocomposite scaffold a potential material for bone tissue engineering: An In Vitro study. Int. J. Biol. Macromol. 2020, 151, 584-594. [CrossRef] [PubMed]

15. Khan, M.U.A.; Raza, M.A.; Razak, S.I.A.; Abdul Kadir, M.R.; Haider, A.; Shah, S.A.; Mohd Yusof, A.H.; Haider, S.; Shakir, I.; Aftab, S. Novel functional antimicrobial and biocompatible arabinoxylan/guar gum hydrogel for skin wound dressing applications. J. Tissue Eng. Regen. Med. 2020, 10, 1488-1501. [CrossRef] [PubMed]

16. Maitz, M.F. Applications of synthetic polymers in clinical medicine. Biosurf. Biotribol. 2015, 1, 161-176. [CrossRef]

17. Ozdil, D.; Aydin, H.M. Polymers for medical and tissue engineering applications. J. Chem. Technol. Biotechnol. 2014, 89, 1793-1810. [CrossRef]

18. Tian, H.; Guo, G.; Fu, X.; Yao, Y.; Yuan, L.; Xiang, A. Fabrication, properties and applications of soy-protein-based materials: A review. Int. J. Biol. Macromol. 2018, 120, 475-490. [CrossRef] [PubMed]

19. Mhd Haniffa, M.A.C.; Ching, Y.C.; Abdullah, L.C.; Poh, S.C.; Chuah, C.H. Review of bionanocomposite coating films and their applications. Polymers 2016, 8, 246. [CrossRef]

20. Trache, D.; Hussin, M.H.; Chuin, C.T.H.; Sabar, S.; Fazita, M.N.; Taiwo, O.F.; Hassan, T.; Haafiz, M.M. Microcrystalline cellulose: Isolation, characterization and bio-composites application-A review. Int. J. Biol. Macromol. 2016, 93, 789-804. [CrossRef]

21. Awal, A.; Rana, M.; Sain, M. Thermorheological and mechanical properties of cellulose reinforced PLA bio-composites. Mech. Mater. 2015, 80, 87-95. [CrossRef]

22. Khan, M.U.A.; Haider, S.; Haider, A.; Kadir, M.R.A.; Abd Razak, S.I.; Shah, S.A.; Javad, A.; Shakir, I.; Al-Zahrani, A.A. Development of Porous, Antibacterial and Biocompatible GO/n-HAp/Bacterial Cellulose/ $\beta$-Glucan Biocomposite Scaffold for Bone Tissue Engineering. Arab. J. Chem. 2020, 14, 102924.

23. Wooster, T.J.; Day, L.; Xu, M.; Golding, M.; Oiseth, S.; Keogh, J.; Clifton, P. Impact of different biopolymer networks on the digestion of gastric structured emulsions. Food Hydrocoll. 2014, 36, 102-114. [CrossRef]

24. Nascimento, D.M.; Nunes, Y.L.; Figueirêdo, M.C.; de Azeredo, H.M.; Aouada, F.A.; Feitosa, J.P.; Rosa, M.F.; Dufresne, A. Nanocellulose nanocomposite hydrogels: Technological and environmental issues. Green Chem. 2018, 20, 2428-2448. [CrossRef]

25. Isikgor, F.H.; Becer, C.R. Lignocellulosic biomass: A sustainable platform for the production of bio-based chemicals and polymers. Polym. Chem. 2015, 6, 4497-4559. [CrossRef]

26. Khalil, H.A.; Davoudpour, Y.; Saurabh, C.K.; Hossain, M.S.; Adnan, A.; Dungani, R.; Paridah, M.; Sarker, M.Z.I.; Fazita, M.N.; Syakir, M. A review on nanocellulosic fibres as new material for sustainable packaging: Process and applications. Renew. Sustain. Energy Rev. 2016, 64, 823-836. [CrossRef]

27. Groover, M.P. Fundamentals of Modern Manufacturing: Materials, Processes, and Systems; John Wiley \& Sons: Hoboken, NJ, USA, 2020.

28. Ketonen, M. Applying LCA in product development and design: Sustainable design in bio-based plastic-glass fibre composite for durable applications. Master's Thesis, Tampere University of Applied Sciences, Tampere, Finland, January 2020.

29. Kamble, S.S.; Gunasekaran, A.; Gawankar, S.A. Sustainable Industry 4.0 framework: A systematic literature review identifying the current trends and future perspectives. Process. Saf. Environ. Prot. 2018, 117, 408-425. [CrossRef]

30. Somuncu, Ö.S.; Karahan, C.; Somuncu, S.; Şahin, F. Tissue Engineering for Skin Replacement Methods. Stem Cells Clin. Pract. Tissue Eng. 2018, 315. [CrossRef]

31. Chen, L.; Ge, M.-D.; Zhu, Y.-J.; Song, Y.; Cheung, P.C.; Zhang, B.-B.; Liu, L.-M. Structure, bioactivity and applications of natural hyperbranched polysaccharides. Carbohydr. Polym. 2019, 223, 115076. [CrossRef]

32. Sun, J.; Tan, H. Alginate-based biomaterials for regenerative medicine applications. Materials 2013, 6, 1285-1309. [CrossRef]

33. Teodorescu, M.; Bercea, M.; Morariu, S. Biomaterials of PVA and PVP in medical and pharmaceutical applications: Perspectives and challenges. Biotechnol. Adv. 2019, 37, 109-131. [CrossRef]

34. Patra, J.K.; Das, G.; Fraceto, L.F.; Campos, E.V.R.; del Pilar Rodriguez-Torres, M.; Acosta-Torres, L.S.; Diaz-Torres, L.A.; Grillo, R.; Swamy, M.K.; Sharma, S. Nano based drug delivery systems: Recent developments and future prospects. J. Nanobiotechnol. 2018, 16, 71. [CrossRef]

35. Nguyen, T.P.; Nguyen, Q.V.; Nguyen, V.-H.; Le, T.-H.; Huynh, V.Q.N.; Vo, D.-V.N.; Trinh, Q.T.; Kim, S.Y.; Le, Q.V. Silk fibroin-based biomaterials for biomedical applications: A review. Polymers 2019, 11, 1933. [CrossRef]

36. Qin, G.; Kai, X. Advanced Materials for Biomedical Engineering Applications. In Design, Fabrication, Properties and Applications of Smart and Advanced Materials; CRC Press: Boca Raton, FL, USA, 2016; pp. 384-420.

37. Lee, E.S.; Gao, Z.; Bae, Y.H. Recent progress in tumor pH targeting nanotechnology. J. Control. Release 2008, 132, 164-170. [CrossRef] [PubMed]

38. Manchun, S.; Dass, C.R.; Sriamornsak, P. Targeted therapy for cancer using pH-responsive nanocarrier systems. Life Sci. 2012, 90, 381-387. [CrossRef]

39. Pant, B.; Park, M.; Park, S.-J. Drug delivery applications of core-sheath nanofibers prepared by coaxial electrospinning: A review. Pharmaceutics 2019, 11, 305. [CrossRef] [PubMed] 
40. Meghani, N.M.; Amin, H.H.; Lee, B.-J. Mechanistic applications of click chemistry for pharmaceutical drug discovery and drug delivery. Drug Discov. Today 2017, 22, 1604-1619. [CrossRef] [PubMed]

41. Li, X.; Lu, C.; Yang, Y.; Yu, C.; Rao, Y. Site-specific targeted drug delivery systems for the treatment of inflammatory bowel disease. Biomed. Pharmacother. 2020, 129, 110486. [CrossRef] [PubMed]

42. Khosa, A.; Reddi, S.; Saha, R.N. Nanostructured lipid carriers for site-specific drug delivery. Biomed. Pharmacother. 2018, 103, 598-613. [CrossRef] [PubMed]

43. Nazir, S.; Hussain, T.; Ayub, A.; Rashid, U.; MacRobert, A.J. Nanomaterials in combating cancer: Therapeutic applications and developments. Nanomed. Nanotechnol. Biol. Med. 2014, 10, 19-34. [CrossRef]

44. Shah, S.A.; Khan, M.A.; Arshad, M.; Awan, S.; Hashmi, M.; Ahmad, N. Doxorubicin-loaded photosensitive magnetic liposomes for multi-modal cancer therapy. Colloids Surf. B Biointerfaces 2016, 148, 157-164. [CrossRef]

45. Jin, K.; Luo, Z.; Zhang, B.; Pang, Z. Biomimetic nanoparticles for inflammation targeting. Acta Pharm. Sin. B 2018, 8, 23-33. [CrossRef]

46. Liu, Z.; Jiao, Y.; Wang, Y.; Zhou, C.; Zhang, Z. Polysaccharides-based nanoparticles as drug delivery systems. Adv. Drug Deliv. Rev. 2008, 60, 1650-1662. [CrossRef]

47. Zheng, Z.; Eglin, D.; Alini, M.; Richards, G.R.; Qin, L.; Lai, Y. Visible light-induced 3D bioprinting technologies and corresponding bioink materials for tissue engineering: A review. Engineering 2020. [CrossRef]

48. Liu, M.; Zeng, X.; Ma, C.; Yi, H.; Ali, Z.; Mou, X.; Li, S.; Deng, Y.; He, N. Injectable hydrogels for cartilage and bone tissue engineering. Bone Res. 2017, 5, 1-20. [CrossRef] [PubMed]

49. Khademhosseini, A.; Langer, R. A decade of progress in tissue engineering. Nat. Protoc. 2016, 11, 1775-1781. [CrossRef] [PubMed]

50. Madrid, A.P.M.; Vrech, S.M.; Sanchez, M.A.; Rodriguez, A.P. Advances in additive manufacturing for bone tissue engineering scaffolds. Mater. Sci. Eng. C 2019, 100, 631-644. [CrossRef] [PubMed]

51. Noori, A.; Ashrafi, S.J.; Vaez-Ghaemi, R.; Hatamian-Zaremi, A.; Webster, T.J. A review of fibrin and fibrin composites for bone tissue engineering. Int. J. Nanomed. 2017, 12, 4937. [CrossRef]

52. Shadjou, N.; Hasanzadeh, M.; Khalilzadeh, B. Graphene based scaffolds on bone tissue engineering. Bioengineered 2018, 9, 38-47. [CrossRef]

53. Khan, M.U.A.; Raza, M.A.; Mehboob, H.; Kadir, M.R.A.; Abd Razak, S.I.; Shah, S.A.; Iqbal, M.Z.; Amin, R. Development and In Vitro evaluation of $\mathrm{K}$-carrageenan based polymeric hybrid nanocomposite scaffolds for bone tissue engineering. RSC Adv. 2020, 10, 40529-40542. [CrossRef]

54. Al-Arjan, W.S.; Aslam Khan, M.U.; Nazir, S.; Abd Razak, S.I.; Abdul Kadir, M.R. Development of Arabinoxylan-Reinforced Apple Pectin/Graphene Oxide/Nano-Hydroxyapatite Based Nanocomposite Scaffolds with Controlled Release of Drug for Bone Tissue Engineering: In-Vitro Evaluation of Biocompatibility and Cytotoxicity against MC3T3-E1. Coatings 2020, 10, 1120. [CrossRef]

55. Reznikov, N.; Steele, J.; Fratzl, P.; Stevens, M. A materials science vision of extracellular matrix mineralization. Nat. Rev. Mater. 2016, 1, 1-14. [CrossRef]

56. Díaz-Rodríguez, P.; Garcia-Triñanes, P.; López, M.E.; Santoveña, A.; Landin, M. Mineralized alginate hydrogels using marine carbonates for bone tissue engineering applications. Carbohydr. Polym. 2018, 195, 235-242. [CrossRef]

57. Ko, F.C.; Sumner, D.R. How faithfully does intramembranous bone regeneration recapitulate embryonic skeletal development? Dev. Dyn. 2020, 1-16. [CrossRef] [PubMed]

58. Aghajanian, P.; Mohan, S. The art of building bone: Emerging role of chondrocyte-to-osteoblast transdifferentiation in endochondral ossification. Bone Res. 2018, 6, 1-9. [CrossRef]

59. Majidinia, M.; Aghazadeh, J.; Jahanban-Esfahlani, R.; Yousefi, B. The roles of Wnt/ $\beta$-catenin pathway in tissue development and regenerative medicine. J. Cell. Physiol. 2018, 233, 5598-5612. [CrossRef] [PubMed]

60. Jammalamadaka, U.; Tappa, K. Recent advances in biomaterials for 3D printing and tissue engineering. J. Funct. Biomater. 2018, 9, 22. [CrossRef] [PubMed]

61. Azizian, S.; Hadjizadeh, A.; Niknejad, H. Chitosan-gelatin porous scaffold incorporated with Chitosan nanoparticles for growth factor delivery in tissue engineering. Carbohydr. Polym. 2018, 202, 315-322. [CrossRef] [PubMed]

62. Zhao, X.; Han, Y.; Li, J.; Cai, B.; Gao, H.; Feng, W.; Li, S.; Liu, J.; Li, D. BMP-2 immobilized PLGA/hydroxyapatite fibrous scaffold via polydopamine stimulates osteoblast growth. Mater. Sci. Eng. C 2017, 78, 658-666. [CrossRef] [PubMed]

63. Nemati, S.; Kim, S.-J.; Shin, Y.M.; Shin, H. Current progress in application of polymeric nanofibers to tissue engineering. Nano Converg. 2019, 6, 1-16. [CrossRef] [PubMed]

64. Ahangar, P.; Cooke, M.E.; Weber, M.H.; Rosenzweig, D.H. Current biomedical applications of 3D printing and additive manufacturing. Appl. Sci. 2019, 9, 1713. [CrossRef]

65. Ngo, T.D.; Kashani, A.; Imbalzano, G.; Nguyen, K.T.; Hui, D. Additive manufacturing (3D printing): A review of materials, methods, applications and challenges. Compos. Part B Eng. 2018, 143, 172-196. [CrossRef]

66. Attaran, M. The rise of 3-D printing: The advantages of additive manufacturing over traditional manufacturing. Bus. Horiz. 2017, 60, 677-688. [CrossRef]

67. Da Silva, D.; Kaduri, M.; Poley, M.; Adir, O.; Krinsky, N.; Shainsky-Roitman, J.; Schroeder, A. Biocompatibility, biodegradation and excretion of polylactic acid (PLA) in medical implants and theranostic systems. Chem. Eng. J. 2018, 340, 9-14. [CrossRef]

68. Jindal, A.; Mondal, T.; Bhattacharya, J. An In Vitro evaluation of zinc silicate fortified chitosan scaffolds for bone tissue engineering. Int. J. Biol. Macromol. 2020, 164, 4254-4262. [CrossRef] 
69. Pinto, R.V.; Gomes, P.S.; Fernandes, M.H.; Costa, M.E.; Almeida, M.M. Glutaraldehyde-crosslinking chitosan scaffolds reinforced with calcium phosphate spray-dried granules for bone tissue applications. Mater. Sci. Eng. C 2020, 109, 110557. [CrossRef]

70. Law, J.X.; Liau, L.L.; Saim, A.; Yang, Y.; Idrus, R. Electrospun collagen nanofibers and their applications in skin tissue engineering. Tissue Eng. Regen. Med. 2017, 14, 699-718. [CrossRef]

71. Salehi, M.; Farzamfar, S.; Bastami, F.; Tajerian, R. Fabrication and characterization of electrospun PLLA/collagen nanofibrous scaffold coated with chitosan to sustain release of aloe vera gel for skin tissue engineering. Biomed. Eng. Appl. Basis Commun. 2016, 28, 1650035. [CrossRef]

72. Ashwin, B.; Abinaya, B.; Prasith, T.; Chandran, S.V.; Yadav, L.R.; Vairamani, M.; Patil, S.; Selvamurugan, N. 3D-poly (lactic acid) scaffolds coated with gelatin and mucic acid for bone tissue engineering. Int. J. Biol. Macromol. 2020, 162, 523-532. [CrossRef]

73. Olad, A.; Hagh, H.B.K. Graphene oxide and amin-modified graphene oxide incorporated chitosan-gelatin scaffolds as promising materials for tissue engineering. Compos. Part. B Eng. 2019, 162, 692-702. [CrossRef]

74. Adeli-Sardou, M.; Yaghoobi, M.M.; Torkzadeh-Mahani, M.; Dodel, M. Controlled release of lawsone from polycaprolactone/gelatin electrospun nano fibers for skin tissue regeneration. Int. J. Biol. Macromol. 2019, 124, 478-491. [CrossRef]

75. Pezeshki-Modaress, M.; Zandi, M.; Rajabi, S. Tailoring the gelatin/chitosan electrospun scaffold for application in skin tissue engineering: An In Vitro study. Prog. Biomater. 2018, 7, 207-218. [CrossRef]

76. Wang, J.; Bai, J.; Fan, M.; Li, T.; Li, Y.; Qian, H.; Wang, L.; Zhang, H.; Qi, X.; Rao, Z. Cereal-derived arabinoxylans: Structural features and structure-activity correlations. Trends Food Sci. Technol. 2020, 96, 157-165. [CrossRef]

77. Ogawa, K.; Takeuchi, M.; Nakamura, N. Immunological effects of partially hydrolyzed arabinoxylan from corn husk in mice. Biosci. Biotechnol. Biochem. 2005, 69, 19-25. [CrossRef] [PubMed]

78. Dewle, A.; Pathak, N.; Rakshasmare, P.; Srivastava, A. Multifarious fabrication approaches of producing aligned collagen scaffolds for tissue engineering applications. ACS Biomater. Sci. Eng. 2020, 6, 779-797. [CrossRef]

79. Song, Y.; Wu, H.; Gao, Y.; Li, J.; Lin, K.; Liu, B.; Lei, X.; Cheng, P.; Zhang, S.; Wang, Y. Zinc Silicate/Nano-Hydroxyapatite/Collagen Scaffolds Promote Angiogenesis and Bone Regeneration via the p38 MAPK Pathway in Activated Monocytes. ACS Appl. Mater. Interfaces 2020, 12, 16058-16075. [CrossRef] [PubMed]

80. Sharif, S.; Ai, J.; Azami, M.; Verdi, J.; Atlasi, M.A.; Shirian, S.; Samadikuchaksaraei, A. Collagen-coated nano-electrospun PCL seeded with human endometrial stem cells for skin tissue engineering applications. J. Biomed. Mater. Res. Part B Appl. Biomater. 2018, 106, 1578-1586. [CrossRef] [PubMed]

81. Aslam Khan, M.U.; Mehboob, H.; Abd Razak, S.I.; Yahya, M.Y.; Mohd Yusof, A.H.; Ramlee, M.H.; Sahaya Anand, T.J.; Hassan, R.; Aziz, A.; Amin, R. Development of Polymeric Nanocomposite (Xyloglucan-co-Methacrylic Acid/Hydroxyapatite/SiO2) Scaffold for Bone Tissue Engineering Applications-In-Vitro Antibacterial, Cytotoxicity and Cell Culture Evaluation. Polymers 2020, 12, 1238. [CrossRef]

82. Bourquin, V.; Nishikubo, N.; Abe, H.; Brumer, H.; Denman, S.; Eklund, M.; Christiernin, M.; Teeri, T.T.; Sundberg, B.; Mellerowicz, E.J. Xyloglucan endotransglycosylases have a function during the formation of secondary cell walls of vascular tissues. Plant. Cell 2002, 14, 3073-3088. [CrossRef]

83. Almeida, A.R.; Bessa-Gonçalves, M.; Vasconcelos, D.M.; Barbosa, M.A.; Santos, S.G. Osteoclasts degrade fibrinogen scaffolds and induce mesenchymal stem/stromal osteogenic differentiation. J. Biomed. Mater. Res. Part A 2020, 108, 851-862. [CrossRef]

84. Woods, I.; Black, A.; Molloy, E.J.; Jockenhoevel, S.; Flanagan, T.C. Fabrication of blood-derived elastogenic vascular grafts using electrospun fibrinogen and polycaprolactone composite scaffolds for paediatric applications. J. Tissue Eng. Regen. Med. 2020, 14, 1281-1295. [CrossRef]

85. Underwood, S.; Afoke, A.; Brown, R.; MacLeod, A.; Shamlou, P.A.; Dunnill, P. Wet extrusion of fibronectin-fibrinogen cables for application in tissue engineering. Biotechnol. Bioeng. 2001, 73, 295-305. [CrossRef]

86. Laidmäe, I.; Ërglis, K.; Cēbers, A.; Janmey, P.A.; Uibo, R. Salmon fibrinogen and chitosan scaffold for tissue engineering: In vitro and In Vivo evaluation. J. Mater. Sci. Mater. Med. 2018, 29, 182. [CrossRef]

87. Makvandi, P.; Ali, G.W.; Della Sala, F.; Abdel-Fattah, W.I.; Borzacchiello, A. Hyaluronic acid/corn silk extract based injectable nanocomposite: A biomimetic antibacterial scaffold for bone tissue regeneration. Mater. Sci. Eng. C 2020, 107, 110195. [CrossRef] [PubMed]

88. Zhou, Y.; Gu, Z.; Liu, J.; Huang, K.; Liu, G.; Wu, J. Arginine based poly (ester amide)/hyaluronic acid hybrid hydrogels for bone tissue Engineering. Carbohydr. Polym. 2020, 230, 115640. [CrossRef] [PubMed]

89. Monteiro, I.P.; Shukla, A.; Marques, A.P.; Reis, R.L.; Hammond, P.T. Spray-assisted layer-by-layer assembly on hyaluronic acid scaffolds for skin tissue engineering. J. Biomed. Mater. Res. Part A 2015, 103, 330-340. [CrossRef] [PubMed]

90. Allison, D.D.; Grande-Allen, K.J. Hyaluronan: A powerful tissue engineering tool. Tissue Eng. 2006, 12, 2131-2140. [CrossRef] [PubMed]

91. Khan, M.U.A.; Al-Thebaiti, M.A.; Hashmi, M.U.; Aftab, S.; Abd Razak, S.I.; Abu Hassan, S.; Abdul Kadir, M.R.; Amin, R. Synthesis of Silver-Coated Bioactive Nanocomposite Scaffolds Based on Grafted Beta-Glucan/Hydroxyapatite via Freeze-Drying Method: Anti-Microbial and Biocompatibility Evaluation for Bone Tissue Engineering. Materials 2020, 13, 971. [CrossRef]

92. Sahana, T.; Rekha, P. Biopolymers: Applications in wound healing and skin tissue engineering. Mol. Biol. Rep. 2018, 45, $2857-2867$. [CrossRef]

93. Chaudhari, A.A.; Vig, K.; Baganizi, D.R.; Sahu, R.; Dixit, S.; Dennis, V.; Singh, S.R.; Pillai, S.R. Future prospects for scaffolding methods and biomaterials in skin tissue engineering: A review. Int. J. Mol. Sci. 2016, 17, 1974. [CrossRef] 
94. Beheshtizadeh, N.; Lotfibakhshaiesh, N.; Pazhouhnia, Z.; Hoseinpour, M.; Nafari, M. A review of 3D bio-printing for bone and skin tissue engineering: A commercial approach. J. Mater. Sci. 2020, 55, 3729-3749. [CrossRef]

95. Zarrintaj, P.; Moghaddam, A.S.; Manouchehri, S.; Atoufi, Z.; Amiri, A.; Amirkhani, M.A.; Nilforoushzadeh, M.A.; Saeb, M.R.; Hamblin, M.R.; Mozafari, M. Can regenerative medicine and nanotechnology combine to heal wounds? The search for the ideal wound dressing. Nanomedicine 2017, 12, 2403-2422. [CrossRef]

96. Karabourniotis, G.; Liakopoulos, G.; Nikolopoulos, D.; Bresta, P. Protective and defensive roles of non-glandular trichomes against multiple stresses: Structure-function coordination. J. For. Res. 2020, 31, 1-12. [CrossRef]

97. Vijayavenkataraman, S.; Lu, W.; Fuh, J. 3D bioprinting of skin: A state-of-the-art review on modelling, materials, and processes. Biofabrication 2016, 8, 032001. [CrossRef] [PubMed]

98. Shukla, T.; Upmanyu, N.; Agrawal, M.; Saraf, S.; Saraf, S.; Alexander, A. Biomedical applications of microemulsion through dermal and transdermal route. Biomed. Pharmacother. 2018, 108, 1477-1494. [CrossRef] [PubMed]

99. Cole, M.A.; Quan, T.; Voorhees, J.J.; Fisher, G.J. Extracellular matrix regulation of fibroblast function: Redefining our perspective on skin aging. J. Cell Commun. Signal. 2018, 12, 35-43. [CrossRef] [PubMed]

100. Uehara, E.; Hokazono, H.; Hida, M.; Sasaki, T.; Yoshioka, H.; Matsuo, N. GABA promotes elastin synthesis and elastin fiber formation in normal human dermal fibroblasts (HDFs). Biosci. Biotechnol. Biochem. 2017, 81, 1198-1205. [CrossRef]

101. Vazina, A.A.; Vasiliev, V.; Vasilieva, A.; Vasilchenko, V.; Gichka, S.; Zabelin, A.; Kvasha, M.; Korneev, V.; Kulipanov, G.; Lanina, N. Nanostructural Mechanism of Modifying Adaptation of Proteoglycan Systems of Biological Tissues and Mucus. Crystallogr. Rep. 2018, 63, 1063-1070. [CrossRef]

102. Guimarães, C.F.; Gasperini, L.; Marques, A.P.; Reis, R.L. The stiffness of living tissues and its implications for tissue engineering. Nat. Rev. Mater. 2020, 5, 351-370. [CrossRef]

103. Vig, K.; Chaudhari, A.; Tripathi, S.; Dixit, S.; Sahu, R.; Pillai, S.; Dennis, V.A.; Singh, S.R. Advances in skin regeneration using tissue engineering. Int. J. Mol. Sci. 2017, 18, 789. [CrossRef]

104. Waldmann, V.; Narayanan, K.; Combes, N.; Jost, D.; Jouven, X.; Marijon, E. Electrical cardiac injuries: Current concepts and management. Eur. Heart J. 2018, 39, 1459-1465. [CrossRef]

105. Holle, A.W.; Young, J.L.; Van Vliet, K.J.; Kamm, R.D.; Discher, D.; Janmey, P.; Spatz, J.P.; Saif, T. Cell-extracellular matrix mechanobiology: Forceful tools and emerging needs for basic and translational research. Nano Lett. 2018, 18, 1-8. [CrossRef]

106. Roy, R.; Tiwari, M.; Donelli, G.; Tiwari, V. Strategies for combating bacterial biofilms: A focus on anti-biofilm agents and their mechanisms of action. Virulence 2018, 9, 522-554. [CrossRef]

107. Tite, T.; Popa, A.-C.; Balescu, L.M.; Bogdan, I.M.; Pasuk, I.; Ferreira, J.M.; Stan, G.E. Cationic substitutions in hydroxyapatite: Current status of the derived biofunctional effects and their In Vitro interrogation methods. Materials 2018, 11, 2081. [CrossRef] [PubMed]

108. Man, E.; Hoskins, C. Towards advanced wound regeneration. Eur. J. Pharm. Sci. 2020, 149, 105360. [CrossRef]

109. Augustine, R. Skin bioprinting: A novel approach for creating artificial skin from synthetic and natural building blocks. Prog. Biomater. 2018, 7, 77-92. [CrossRef]

110. Roseti, L.; Parisi, V.; Petretta, M.; Cavallo, C.; Desando, G.; Bartolotti, I.; Grigolo, B. Scaffolds for bone tissue engineering: State of the art and new perspectives. Mater. Sci. Eng. C 2017, 78, 1246-1262. [CrossRef]

111. Youngson, R.M. Surgery Book: An Illustrated Guide to 73 of the Most Common Operations; Macmillan: New York, NY, USA, 1997.

112. Shah, N.; Ul-Islam, M.; Khattak, W.A.; Park, J.K. Overview of bacterial cellulose composites: A multipurpose advanced material. Carbohydr. Polym. 2013, 98, 1585-1598. [CrossRef]

113. Patil, N.; Jerome, C.; Detrembleur, C. Recent advances in the synthesis of catechol-derived (bio) polymers for applications in energy storage and environment. Prog. Polym. Sci. 2018, 82, 34-91. [CrossRef]

114. Eivazzadeh-Keihan, R.; Maleki, A.; De La Guardia, M.; Bani, M.S.; Chenab, K.K.; Pashazadeh-Panahi, P.; Baradaran, B.; Mokhtarzadeh, A.; Hamblin, M.R. Carbon based nanomaterials for tissue engineering of bone: Building new bone on small black scaffolds: A review. J. Adv. Res. 2019, 18, 185-201. [CrossRef]

115. Cavazza, A.; Miccio, A.; Romano, O.; Petiti, L.; Tagliazucchi, G.M.; Peano, C.; Severgnini, M.; Rizzi, E.; De Bellis, G.; Bicciato, S. Dynamic transcriptional and epigenetic regulation of human epidermal keratinocyte differentiation. Stem Cell Rep. 2016, 6, 618-632. [CrossRef] [PubMed]

116. Li, Y.; Zhang, J.; Yue, J.; Gou, X.; Wu, X. Epidermal stem cells in skin wound healing. Adv. Wound Care 2017, 6, 297-307. [CrossRef]

117. Jackson, C.J.; Tønseth, K.A.; Utheim, T.P. Cultured epidermal stem cells in regenerative medicine. Stem Cell Res. Ther. 2017, 8, 1-7. [CrossRef]

118. Advedissian, T.; Proux-Gillardeaux, V.; Nkosi, R.; Peyret, G.; Nguyen, T.; Poirier, F.; Viguier, M.; Deshayes, F. E-cadherin dynamics is regulated by galectin-7 at epithelial cell surface. Sci. Rep. 2017, 7, 17086. [CrossRef]

119. Kucharzewski, M.; Rojczyk, E.; Wilemska-Kucharzewska, K.; Wilk, R.; Hudecki, J.; Los, M.J. Novel trends in application of stem cells in skin wound healing. Eur. J. Pharmacol. 2019, 843, 307-315. [CrossRef]

120. Li, Z.; Maitz, P. Cell therapy for severe burn wound healing. Burn. Trauma 2018, 6. [CrossRef]

121. Kim, H.S.; Sun, X.; Lee, J.-H.; Kim, H.-W.; Fu, X.; Leong, K.W. Advanced drug delivery systems and artificial skin grafts for skin wound healing. Adv. Drug Deliv. Rev. 2019, 146, 209-239. [CrossRef]

122. Lee, Y.; Park, J.; Choe, A.; Cho, S.; Kim, J.; Ko, H. Mimicking human and biological skins for multifunctional skin electronics. Adv. Funct. Mater. 2020, 30, 1904523. [CrossRef] 
123. Yadollahpour, A.; Mostafa, J.; Samaneh, R.; Zohreh, R. Ultrasound therapy for wound healing: A review of current techniques and mechanisms of action. J. Pure Appl. Microbiol. 2014, 8, 4071-4085.

124. Loots, M.A.; Lamme, E.N.; Zeegelaar, J.; Mekkes, J.R.; Bos, J.D.; Middelkoop, E. Differences in cellular infiltrate and extracellular matrix of chronic diabetic and venous ulcers versus acute wounds. J. Investig. Dermatol. 1998, 111, 850-857. [CrossRef] [PubMed]

125. Carroll, L.; Cassidy, J.D.; Peloso, P.; Borg, J.; Von Holst, H.; Holm, L.; Paniak, C.; Pépin, M. Prognosis for mild traumatic brain injury: Results of the WHO Collaborating Centre Task Force on Mild Traumatic Brain Injury. J. Rehabil. Med. 2004, 36, 84-105. [CrossRef]

126. Belliere, J.; Meyer, N.; Mazieres, J.; Ollier, S.; Boulinguez, S.; Delas, A.; Ribes, D.; Faguer, S. Acute interstitial nephritis related to immune checkpoint inhibitors. Br. J. Cancer 2016, 115, 1457-1461. [CrossRef]

127. Rahim, K.; Saleha, S.; Zhu, X.; Huo, L.; Basit, A.; Franco, O.L. Bacterial contribution in chronicity of wounds. Microb. Ecol. 2017, 73, 710-721. [CrossRef]

128. Tate, S.; Harding, K. Chronic Wound Healing: Molecular and Biochemical Basis. Ther. Dress. Wound Heal. Appl. 2020, 1-19. [CrossRef]

129. Wang, Y.; Beekman, J.; Hew, J.; Jackson, S.; Issler-Fisher, A.C.; Parungao, R.; Lajevardi, S.S.; Li, Z.; Maitz, P.K. Burn injury: Challenges and advances in burn wound healing, infection, pain and scarring. Adv. Drug Deliv. Rev. 2018, 123, 3-17. [CrossRef] [PubMed]

130. Kanji, S.; Das, H. Advances of stem cell therapeutics in cutaneous wound healing and regeneration. Mediat. Inflamm. 2017, 2017, 5217967. [CrossRef]

131. Tavakoli, S.; Klar, A.S. Advanced Hydrogels as Wound Dressings. Biomolecules 2020, 10, 1169. [CrossRef]

132. Lopes, D.; Martins-Cruz, C.; Oliveira, M.B.; Mano, J.F. Bone physiology as inspiration for tissue regenerative therapies. Biomaterials 2018, 185, 240-275. [CrossRef]

133. Pourshahrestani, S.; Zeimaran, E.; Kadri, N.A.; Mutlu, N.; Boccaccini, A.R. Polymeric Hydrogel Systems as Emerging Biomaterial Platforms to Enable Hemostasis and Wound Healing. Adv. Healthc. Mater. 2020, 9, 2000905. [CrossRef]

134. Berghoff, S.A.; Gerndt, N.; Winchenbach, J.; Stumpf, S.K.; Hosang, L.; Odoardi, F.; Ruhwedel, T.; Böhler, C.; Barrette, B.; Stassart, R. Dietary cholesterol promotes repair of demyelinated lesions in the adult brain. Nat. Commun. 2017, 8, 1-15. [CrossRef] [PubMed]

135. Akbari, S.; Rasouli-Ghahroudi, A.A. Vitamin K and bone metabolism: A review of the latest evidence in preclinical studies. Biomed Res. Int. 2018, 2018, 4629383. [CrossRef] [PubMed]

136. Mussbacher, M.; Salzmann, M.; Brostjan, C.; Hoesel, B.; Schoergenhofer, C.; Datler, H.; Hohensinner, P.; Basílio, J.; Petzelbauer, P.; Assinger, A. Cell type-specific roles of NF-kB linking inflammation and thrombosis. Front. Immunol. 2019, 10, 85. [CrossRef] [PubMed]

137. Andrews, A. Effects of the Periodontal Pathogens Porphyromonas Gingivalis and Tannerella Forsythia on Platelets; Sheffield Hallam University: Sheffield, UK, 2018.

138. Worrall, S. Investigating the Role of Nitrite in the Cardiovascular System; University of Birmingham: Birmingham, UK, 2019.

139. Mogoşanu, G.D.; Grumezescu, A.M. Natural and synthetic polymers for wounds and burns dressing. Int. J. Pharm. 2014, 463, 127-136. [CrossRef] [PubMed]

140. Xue, M.; Jackson, C.J. Extracellular matrix reorganization during wound healing and its impact on abnormal scarring. Adv. Wound Care 2015, 4, 119-136. [CrossRef] [PubMed]

141. Hu, M.S.; Maan, Z.N.; Wu, J.-C.; Rennert, R.C.; Hong, W.X.; Lai, T.S.; Cheung, A.T.; Walmsley, G.G.; Chung, M.T.; McArdle, A. Tissue engineering and regenerative repair in wound healing. Ann. Biomed. Eng. 2014, 42, 1494-1507. [CrossRef] [PubMed]

142. Kharkar, P.M.; Rehmann, M.S.; Skeens, K.M.; Maverakis, E.; Kloxin, A.M. Thiol-ene click hydrogels for therapeutic delivery. ACS Biomater. Sci. Eng. 2016, 2, 165-179. [CrossRef] [PubMed]

143. Jiang, Y.; Chen, J.; Deng, C.; Suuronen, E.J.; Zhong, Z. Click hydrogels, microgels and nanogels: Emerging platforms for drug delivery and tissue engineering. Biomaterials 2014, 35, 4969-4985. [CrossRef] [PubMed]

144. Aduba, D.C., Jr.; An, S.-S.; Selders, G.S.; Yeudall, W.A.; Bowlin, G.L.; Kitten, T.; Yang, H. Electrospun gelatin-arabinoxylan ferulate composite fibers for diabetic chronic wound dressing application. Int. J. Polym. Mater. Polym. Biomater. 2019, 68, 660-668. [CrossRef]

145. Balakrishnan, B.; Mohanty, M.; Umashankar, P.; Jayakrishnan, A. Evaluation of an in situ forming hydrogel wound dressing based on oxidized alginate and gelatin. Biomaterials 2005, 26, 6335-6342. [CrossRef]

146. Tanaka, A.; Nagate, T.; Matsuda, H. Acceleration of wound healing by gelatin film dressings with epidermal growth factor. J. Vet. Med Sci. 2005, 67, 909-913. [CrossRef]

147. Gaspar-Pintiliescu, A.; Stanciuc, A.-M.; Craciunescu, O. Natural composite dressings based on collagen, gelatin and plant bioactive compounds for wound healing: A review. Int. J. Biol. Macromol. 2019, 138, 854-865. [CrossRef]

148. Grip, J.; Engstad, R.E.; Skjæveland, I.; Škalko-Basnet, N.; Isaksson, J.; Basnet, P.; Holsæter, A.M. Beta-glucan-loaded nanofiber dressing improves wound healing in diabetic mice. Eur. J. Pharm. Sci. 2018, 121, 269-280. [CrossRef]

149. Chen, J.; Raymond, K. Beta-glucans in the treatment of diabetes and associated cardiovascular risks. Vasc. Health Risk Manag. 2008, 4, 1265. [CrossRef]

150. Seo, G.; Hyun, C.; Choi, S.; Kim, Y.M.; Cho, M. The wound healing effect of four types of beta-glucan. Appl. Biol. Chem. 2019, 62, 20. [CrossRef]

151. Patrulea, V.; Ostafe, V.; Borchard, G.; Jordan, O. Chitosan as a starting material for wound healing applications. Eur. J. Pharm. Biopharm. 2015, 97, 417-426. [CrossRef]

152. Ahmed, S.; Ikram, S. Chitosan based scaffolds and their applications in wound healing. Achiev. Life Sci. 2016, 10, 27-37. [CrossRef]

153. He, J.; Liang, Y.; Shi, M.; Guo, B. Anti-oxidant electroactive and antibacterial nanofibrous wound dressings based on poly ( $\varepsilon$ caprolactone)/quaternized chitosan-graft-polyaniline for full-thickness skin wound healing. Chem. Eng. J. 2020, 385, 123464. [CrossRef] 
154. Masood, N.; Ahmed, R.; Tariq, M.; Ahmed, Z.; Masoud, M.S.; Ali, I.; Asghar, R.; Andleeb, A.; Hasan, A. Silver nanoparticle impregnated chitosan-PEG hydrogel enhances wound healing in diabetes induced rabbits. Int. J. Pharm. 2019, 559, 23-36. [CrossRef] [PubMed]

155. Ehterami, A.; Salehi, M.; Farzamfar, S.; Samadian, H.; Vaez, A.; Ghorbani, S.; Ai, J.; Sahrapeyma, H. Chitosan/alginate hydrogels containing Alpha-tocopherol for wound healing in rat model. J. Drug Deliv. Sci. Technol. 2019, 51, 204-213. [CrossRef]

156. Zare-Gachi, M.; Daemi, H.; Mohammadi, J.; Baei, P.; Bazgir, F.; Hosseini-Salekdeh, S.; Baharvand, H. Improving anti-hemolytic, antibacterial and wound healing properties of alginate fibrous wound dressings by exchanging counter-cation for infected full-thickness skin wounds. Mater. Sci. Eng. C 2020, 107, 110321. [CrossRef] [PubMed]

157. Alavi, M.; Nokhodchi, A. An overview on antimicrobial and wound healing properties of ZnO nanobiofilms, hydrogels, and bionanocomposites based on cellulose, chitosan, and alginate polymers. Carbohydr. Polym. 2020, 227, 115349. [CrossRef] [PubMed]

158. Lin, Z.; Wu, T.; Wang, W.; Li, B.; Wang, M.; Chen, L.; Xia, H.; Zhang, T. Biofunctions of antimicrobial peptide-conjugated alginate/hyaluronic acid/collagen wound dressings promote wound healing of a mixed-bacteria-infected wound. Int. J. Biol. Macromol. 2019, 140, 330-342. [CrossRef]

159. Stapelfeldt, K.; Stamboroski, S.; Walter, I.; Suter, N.; Kowalik, T.; Michaelis, M.; Bruüggemann, D. Controlling the multiscale structure of nanofibrous fibrinogen scaffolds for wound healing. Nano Lett. 2019, 19, 6554-6563. [CrossRef]

160. Zhao, N.; Coyne, J.; Xu, M.; Zhang, X.; Suzuki, A.; Shi, P.; Lai, J.; Fong, G.-H.; Xiong, N.; Wang, Y. Assembly of bifunctional aptamer-fibrinogen macromer for VEGF delivery and skin wound healing. Chem. Mater. 2019, 31, 1006-1015. [CrossRef]

161. Picone, P.; Sabatino, M.A.; Ajovalasit, A.; Giacomazza, D.; Dispenza, C.; Di Carlo, M. Biocompatibility, hemocompatibility and antimicrobial properties of xyloglucan-based hydrogel film for wound healing application. Int. J. Biol. Macromol. 2019, 121, 784-795. [CrossRef]

162. Ajovalasit, A.; Sabatino, M.A.; Todaro, S.; Alessi, S.; Giacomazza, D.; Picone, P.; Di Carlo, M.; Dispenza, C. Xyloglucan-based hydrogel films for wound dressing: Structure-property relationships. Carbohydr. Polym. 2018, 179, 262-272. [CrossRef]

163. Hirose, K.; Sasatsu, M.; Toraishi, T.; Onishi, H. Novel Xyloglucan Sheet for the Treatment of Deep Wounds: Preparation, Physicochemical Characteristics, and In Vivo Healing Effects. Biol. Pharm. Bull. 2019, 42, 1409-1414. [CrossRef]

164. Qiu, Y.; Qiu, L.; Cui, J.; Wei, Q. Bacterial cellulose and bacterial cellulose-vaccarin membranes for wound healing. Mater. Sci. Eng. C 2016, 59, 303-309. [CrossRef]

165. Lin, W.-C.; Lien, C.-C.; Yeh, H.-J.; Yu, C.-M.; Hsu, S.-H. Bacterial cellulose and bacterial cellulose-chitosan membranes for wound dressing applications. Carbohydr. Polym. 2013, 94, 603-611. [CrossRef]

166. Giusto, G.; Vercelli, C.; Comino, F.; Caramello, V.; Tursi, M.; Gandini, M. A new, easy-to-make pectin-honey hydrogel enhances wound healing in rats. BMC Complement. Altern. Med. 2017, 17, 1-7. [CrossRef]

167. Kocaaga, B.; Kurkcuoglu, O.; Tatlier, M.; Batirel, S.; Guner, F.S. Low-methoxyl pectin-zeolite hydrogels controlling drug release promote In Vitro wound healing. J. Appl. Polym. Sci. 2019, 136, 47640. [CrossRef]

168. Biranje, S.S.; Madiwale, P.V.; Patankar, K.C.; Chhabra, R.; Bangde, P.; Dandekar, P.; Adivarekar, R.V. Cytotoxicity and hemostatic activity of chitosan/carrageenan composite wound healing dressing for traumatic hemorrhage. Carbohydr. Polym. 2020, 239 , 116106. [CrossRef]

169. Shanmugapriya, K.; Kim, H.; Kang, H.W. A new alternative insight of nanoemulsion conjugated with K-carrageenan for wound healing study in diabetic mice: In Vitro and In Vivo evaluation. Eur. J. Pharm. Sci. 2019, 133, 236-250. [CrossRef]

170. Murakami, K.; Aoki, H.; Nakamura, S.; Nakamura, S.-I.; Takikawa, M.; Hanzawa, M.; Kishimoto, S.; Hattori, H.; Tanaka, Y.; Kiyosawa, T. Hydrogel blends of chitin/chitosan, fucoidan and alginate as healing-impaired wound dressings. Biomaterials 2010, 31, 83-90. [CrossRef] [PubMed]

171. Park, J.-H.; Choi, S.-H.; Park, S.-J.; Lee, Y.J.; Park, J.H.; Song, P.H.; Cho, C.-M.; Ku, S.-K.; Song, C.-H. Promoting wound healing using low molecular weight fucoidan in a full-thickness dermal excision rat model. Mar. Drugs 2017, 15, 112. [CrossRef] [PubMed]

172. Kordjazi, M.; Shabanpour, B.; Zabihi, E.; Faramarzi, M.A.; Ahmadi Gavlighi, H.; Feghhi, S.M.A.; Hosseini, S.A. Investigation of effects of fucoidan polysaccharides extracted from two species of Padina on the wound-healing process in the rat. Turk. J. Vet. Anim. Sci. 2017, 41. [CrossRef]

173. Fernando, I.S.; Kim, D.; Nah, J.-W.; Jeon, Y.-J. Advances in functionalizing fucoidans and alginates (bio) polymers by structural modifications: A review. Chem. Eng. J. 2019, 355, 33-48. [CrossRef]

174. Chen, X.; Zhai, D.; Wang, B.; Hao, S.; Song, J.; Peng, Z. Hair keratin promotes wound healing in rats with combined radiationwound injury. J. Mater. Sci. Mater. Med. 2020, 31, 1-9. [CrossRef]

175. Gao, F.; Li, W.; Kan, J.; Ding, Y.; Wang, Y.; Deng, J.; Qing, R.; Wang, B.; Hao, S. Insight into the Regulatory Function of Human Hair Keratins in Wound Healing Using Proteomics. Adv. Biosyst. 2020, 4, 1900235. [CrossRef]

176. Hao, Y.; Zhao, W.; Zhang, L.; Zeng, X.; Sun, Z.; Zhang, D.; Shen, P.; Li, Z.; Han, Y.; Li, P. Bio-multifunctional alginate/chitosan/Fucoidan sponges with enhanced angiogenesis and hair follicle regeneration for promoting full-thickness wound healing. Mater. Des. 2020, 193, 108863. [CrossRef]

177. Cheng, L.; Cai, Z.; Ye, T.; Yu, X.; Chen, Z.; Yan, Y.; Qi, J.; Wang, L.; Liu, Z.; Cui, W. Injectable Polypeptide-Protein Hydrogels for Promoting Infected Wound Healing. Adv. Funct. Mater. 2020, 30, 2001196. [CrossRef]

178. Homaeigohar, S.; Tsai, T.-Y.; Zarie, E.S.; Elbahri, M.; Young, T.-H.; Boccaccini, A.R. Bovine Serum Albumin (BSA)/polyacrylonitrile (PAN) biohybrid nanofibers coated with a biomineralized calcium deficient hydroxyapatite (HA) shell for wound dressing. Mater. Sci. Eng. C 2020, 116, 111248. [CrossRef] 
179. Basha, S.I.; Ghosh, S.; Vinothkumar, K.; Ramesh, B.; Mohan, K.M.; Sukumar, E. Fumaric acid incorporated Ag/agar-agar hybrid hydrogel: A multifunctional avenue to tackle wound healing. Mater. Sci. Eng. C 2020, 111, 110743. [CrossRef]

180. Polat, T.G.; Duman, O.; Tunç, S. Agar/k-carrageenan/montmorillonite nanocomposite hydrogels for wound dressing applications. Int. J. Biol. Macromol. 2020. [CrossRef]

181. De Lima, G.G.; de Lima, D.W.; de Oliveira, M.J.; Lugão, A.B.; Alcântara, M.T.; Devine, D.M.; de Sá, M.J. Synthesis and In Vivo behavior of PVP/CMC/agar hydrogel membranes impregnated with silver nanoparticles for wound healing applications. ACS Appl. Bio Mater. 2018, 1, 1842-1852. [CrossRef]

182. Chunshom, N.; Chuysinuan, P.; Techasakul, S.; Ummartyotin, S. Dried-state bacterial cellulose (Acetobacter xylinum) and polyvinyl-alcohol-based hydrogel: An approach to a personal care material. J. Sci. Adv. Mater. Devices 2018, 3, 296-302. [CrossRef]

183. Sridhar, R.; Lakshminarayanan, R.; Madhaiyan, K.; Barathi, V.A.; Lim, K.H.C.; Ramakrishna, S. Electrosprayed nanoparticles and electrospun nanofibers based on natural materials: Applications in tissue regeneration, drug delivery and pharmaceuticals. Chem. Soc. Rev. 2015, 44, 790-814. [CrossRef]

184. Lee, J.H. Injectable hydrogels delivering therapeutic agents for disease treatment and tissue engineering. Biomater. Res. 2018, 22, 1-14. [CrossRef] [PubMed]

185. Li, J.; Mooney, D.J. Designing hydrogels for controlled drug delivery. Nat. Rev. Mater. 2016, 1, 1-17. [CrossRef] [PubMed]

186. Zhang, H.; Zhai, Y.; Wang, J.; Zhai, G. New progress and prospects: The application of nanogel in drug delivery. Mater. Sci. Eng. C 2016, 60, 560-568. [CrossRef]

187. Zhang, Y.; Zhang, J.; Chen, M.; Gong, H.; Thamphiwatana, S.; Eckmann, L.; Gao, W.; Zhang, L. A bioadhesive nanoparticlehydrogel hybrid system for localized antimicrobial drug delivery. ACS Appl. Mater. Interfaces 2016, 8, 18367-18374. [CrossRef]

188. Bai, X.; Gao, M.; Syed, S.; Zhuang, J.; Xu, X.; Zhang, X.-Q. Bioactive hydrogels for bone regeneration. Bioact. Mater. 2018, 3, 401-417. [CrossRef] [PubMed]

189. Chen, M.-C.; Lin, Z.-W.; Ling, M.-H. Near-infrared light-activatable microneedle system for treating superficial tumors by combination of chemotherapy and photothermal therapy. ACS Nano 2016, 10, 93-101. [CrossRef]

190. Gilbar, P.J. Intrathecal chemotherapy: Potential for medication error. Cancer Nurs. 2014, 37, 299-309. [CrossRef] [PubMed]

191. Xu, Q.; Sigen, A.; Gao, Y.; Guo, L.; Creagh-Flynn, J.; Zhou, D.; Greiser, U.; Dong, Y.; Wang, F.; Tai, H. A hybrid injectable hydrogel from hyperbranched PEG macromer as a stem cell delivery and retention platform for diabetic wound healing. Acta Biomater. 2018, 75, 63-74. [CrossRef]

192. Fu, L.-H.; Qi, C.; Ma, M.-G.; Wan, P. Multifunctional cellulose-based hydrogels for biomedical applications. J. Mater. Chem. B 2019, 7, 1541-1562. [CrossRef] [PubMed]

193. Gu, L.; Mooney, D.J. Biomaterials and emerging anticancer therapeutics: Engineering the microenvironment. Nat. Rev. Cancer 2016, 16, 56-66. [CrossRef] [PubMed]

194. Aamodt, J.M.; Grainger, D.W. Extracellular matrix-based biomaterial scaffolds and the host response. Biomaterials 2016, 86, 68-82. [CrossRef] [PubMed]

195. Tam, R.Y.; Fuehrmann, T.; Mitrousis, N.; Shoichet, M.S. Regenerative therapies for central nervous system diseases: A biomaterials approach. Neuropsychopharmacology 2014, 39, 169-188. [CrossRef]

196. Tan, Y.-X.; Wang, F.; Zhang, J. Design and synthesis of multifunctional metal-organic zeolites. Chem. Soc. Rev. 2018, 47, $2130-2144$. [CrossRef]

197. Kudr, J.; Haddad, Y.; Richtera, L.; Heger, Z.; Cernak, M.; Adam, V.; Zitka, O. Magnetic nanoparticles: From design and synthesis to real world applications. Nanomaterials 2017, 7, 243. [CrossRef]

198. Dong, R.; Zhou, Y.; Huang, X.; Zhu, X.; Lu, Y.; Shen, J. Functional supramolecular polymers for biomedical applications. Adv. Mater. 2015, 27, 498-526. [CrossRef]

199. Gagner, J.E.; Kim, W.; Chaikof, E.L. Designing protein-based biomaterials for medical applications. Acta Biomater. 2014, 10, 1542-1557. [CrossRef]

200. Sinha, R.; Shukla, P. Current trends in protein engineering: Updates and progress. Curr. Protein Pept. Sci. 2019, $20,398-407$. [CrossRef] [PubMed]

201. Van Haasteren, J.; Li, J.; Scheideler, O.J.; Murthy, N.; Schaffer, D.V. The delivery challenge: Fulfilling the promise of therapeutic genome editing. Nat. Biotechnol. 2020, 38, 1-11. [CrossRef]

202. Navya, P.; Daima, H.K. Rational engineering of physicochemical properties of nanomaterials for biomedical applications with nanotoxicological perspectives. Nano Converg. 2016, 3, 1. [CrossRef] [PubMed]

203. Qin, Y.; Zhang, S.; Yu, J.; Yang, J.; Xiong, L.; Sun, Q. Effects of chitin nano-whiskers on the antibacterial and physicochemical properties of maize starch films. Carbohydr. Polym. 2016, 147, 372-378. [CrossRef] [PubMed]

204. Darge, H.F.; Andrgie, A.T.; Tsai, H.-C.; Lai, J.-Y. Polysaccharide and polypeptide based injectable thermo-sensitive hydrogels for local biomedical applications. Int. J. Biol. Macromol. 2019, 133, 545-563. [CrossRef] [PubMed]

205. He, S.; Song, J.; Qu, J.; Cheng, Z. Crucial breakthrough of second near-infrared biological window fluorophores: Design and synthesis toward multimodal imaging and theranostics. Chem. Soc. Rev. 2018, 47, 4258-4278. [CrossRef] [PubMed]

206. Mozhdehi, D.; Luginbuhl, K.M.; Simon, J.R.; Dzuricky, M.; Berger, R.; Varol, H.S.; Huang, F.C.; Buehne, K.L.; Mayne, N.R.; Weitzhandler, I. Genetically encoded lipid-polypeptide hybrid biomaterials that exhibit temperature-triggered hierarchical self-assembly. Nat. Chem. 2018, 10, 496-505. [CrossRef] 
207. Kaplan, D.L. Introduction to biopolymers from renewable resources. In Biopolymers from Renewable Resources; Springer: Berlin, Germany, 1998; pp. 1-29.

208. Hiew, S.H.; Miserez, A. Squid sucker ring teeth: Multiscale structure-property relationships, sequencing, and protein engineering of a thermoplastic biopolymer. ACS Biomater. Sci. Eng. 2017, 3, 680-693. [CrossRef]

209. Reinecke, F.; Steinbuechel, A. Ralstonia eutropha strain H16 as model organism for PHA metabolism and for biotechnological production of technically interesting biopolymers. J. Mol. Microbiol. Biotechnol. 2009, 16, 91-108. [CrossRef] 